\title{
Pengembangan Buku Siswa Berbasis Kontekstual Bermuatan Nilai-Nilai Agama Islam Pada Materi Bioteknologi Kelas XII SMA/MA
}

\author{
Syarifattul Luthfia, Suratno, Erlia Narulita \\ Pendidikan Biologi, Fakultas Keguruan dan Ilmu Pendidikan, Universitas Jember \\ Jl. Kalimantan 37, Jember 68121 \\ E-mail : syarifattul@gmail.com
}

\begin{abstract}
Abstrak
Perkembangan ilmu pengetahuan dan teknologi semakin pesat sehingga bioteknologi sebagai bidang ilmu pengetahuan harus dikuasai oleh bangsa Indonesia. Namun perkembangan bioteknologi saat ini yang semakin pesat membuat beberapa penerapan melanggar etika dan menimbulkan banyak perdebatan di berbagai bidang sehingga perlu adanya norma yang mengatur penerapannya. Upaya peningkatan mutu pembelajaran bioteknologi dapat ditempuh dengan menggunakan bahan ajar yang bermutu, salah satunya adalah buku siswa. Penelitian ini merupakan penelitian pengembangan dan menggunakan model ADDIE yang terdiri dari lima tahap (analisis, desain, pengembangan, implementasi, dan evaluasi). Nilai validitas buku siswa yang dikembangkan sebesar $83,43 \%$ dengan kategori sangat valid. Nilai rata-rata tes keterbacaan dan tingkat kesukaran buku siswa sebesar $91,35 \%$ dengan kategori baik. Nilai praktikum buku siswa 80,67\% dengan kategori praktis. Buku siswa efektif dalam mempengaruhi siswa untuk mencapai kategori baik dalam ranah kognitif, psikomotor, dan afektif. Hasil ini menunjukkan bahwa buku siswa yang dikembangkan dapat digunakan dalam pembelajaran bioteknologi di kelas XII SMA dan MA di Jember.
\end{abstract}

Kata Kunci : Buku Siswa, Pendekatan Kontekstual, Nilai Religius, Model ADDIE

\section{s}

The development of science and technology increasingly rapidly so that biotechnology as a field of science must be controlled by the Indonesian nation. However, the current development of biotechnology is increasingly rapidly making some applications violate the ethics and generate much debate in various areas/so that the norms need to regulate the application. Efforts to improve the quality of biotechnology learning can be pursued by using quality teaching materials ie one of the students' books. This research is a development research and using ADDIE model consisting of five stages (analysis, design, development, implementation, and evaluation). The value of the validity of the books of students who developed for $83.43 \%$ with the category is very valid. The average value of legibility test and student book difficulty level of $91.35 \%$ with good category. Practical value of student's book is $80,67 \%$ with practical category. Student books are effective in influencing students to achieve categories both in the cognitive, psychomotor, and affective domains. These results indicate that the developed student book can be used in biotechnology learning in the XII SMA and MA classes in Jember.

Keywords : Students' Book, Contextual Approach, Religius Values, ADDIE Models

\section{Pendahuluan}

Pembelajaran adalah proses interaksi peserta didik dengan pendidik serta sumber belajar pada lingkungan belajar. Pembelajaran merupakan proses untuk membantu peserta didik agar dapat belajar dengan baik yang dialami sepanjang hayat seorang manusia serta dapat berlaku dimanapun dan kapanpun[13]. Dari hasil pengamatan Standar Kompetensi dan Kompetensi Dasar dalam Permendiknas Nomor 47 Tahun 2008, bioteknologi diajarkan pada sekolah dasar di kelas 4 SD semester 2, pada tingkat SMP di kelas IX semester 1, dan pada tingkat SMA di kelas XII semester 2[11].

EFB (European Federation of Biotechnology) menyatakan bahwa bioteknologi merupakan integrasi dari ilmu pengetahuan alam dan rekayasa yang bertujuan untuk menghasilkan barang dan jasa (baik bioteknologi tradisonal maupun bioteknologi modern)[10]. Bioteknologi adalah ilmu multidisipliner dan aplikatif sehingga membutuhkan penguasaan konsep dasar yang cukup. Perkembangan bioteknologi sangat pesat karena bioteknologi bersentuhan dengan peningkatan taraf hidup manusia[12]. Bioteknologi merupakan ilmu terapan yang mempelajari prinsip-prinsip ilmiah dengan menggunakan organisme atau bagian organisme untuk menghasilkan suatu produk secara industri yang digunakan untuk kepentingan manusia[6].

Konten bioteknologi dalam bidang pedagogis penting dibangun dengan pembelajaran yang solid dan instruksional. Bioteknologi sebagai salah satu bagian dari kurikulum pendidikan teknologi dapat disampaikan menggunakan strategi pengajaran yang memanfaatkan pendekatan instruksional secara kognitif dan konstruktivis (membangun) [7]. Salah satu pendekatan yang bersifat konstruktivisme adalah pendekatan kontekstual. Pembelajaran kontekstual menunjukkan alternatif dalam pembelajaran materi karena aktivitas pembelajaran melalui pembangunan bukan dengan penghapalan dan pembelajaran ditafsirkan sebagai proses aktivitas inquiri yakni tidak hanya transfer pengetahuan terhadap siswa, tetapi siswa diharapkan dapat membangun 
pemahaman mereka sendiri dari pengalaman atau pengetahuan sebelumnya[1].

Realita kehidupan tentang perkembangan ilmu pengetahuan dan teknologi berkembang dengan pesat dan dapat memicu perubahan perilaku, karakter, dan gaya hidup. Pendidikan sebagai usaha sadar dan terencana untuk mewujudkan pembelajaran peserta didik yang aktif mengembangkan potensi dirinya untuk memiliki salah satunya adalah kekuatan spiritual keagamaan [2]. Pendidik perlu melakukan transfer of attitude and values kepada peserta didik. Moral knowing dilakukan untuk memberikan pengetahuan yang baik kepada siswa dengan memberikan alasan kepada anak mengenai makna sebuah nilai. Anak diminta untuk mengklarifikasi terhadap nilai-nilai yang terkandung dalam fenomena yang mereka temukan, membuat siswa mampu memahami nilai-nilai yang baik dan buruk dan efektifitasnya sehingga siswa lebih bijak mengkalrifikasi nilai-nilai yang akan menjadi tindakan dalam kehidupannya[3].

Salah satu wujud perencanaan dalam rangka mempersiapkan pembelajaran adalah dengan membuat bahan ajar. Salah satu jenis bahan ajar adalah buku ajar. Buku ajar merupakan komponen pendidikan yang sangat penting dalam proses pembelajaran. Tersedianya buku ajar yang berkualitas akan mendukung keberhasilan proses pembelajaran[15]. Penelitian menunjukkan bahwa guru masih kesulitan memperoleh sumber bahan ajar memadai yang dibutukan dalam pembelajaran bioteknologi. Bioteknologi merupakan bidang ilmu yang bersifat sangat pesat sehingga dibutuhkan bahan ajar yang bersifat up to date [12].

\section{Metode Penelitian}

Jenis penelitian yang digunakan dalam penelitian ini adalah penelitian dan pengembangan (Research and Development). Model yang digunakan dalam penelitian pengembangan ini adalah model ADDIE (Analysis, Design, Development or Production, Implementation or Delivery, and Evaluations).

Fase awal adalah analisis yang ditempuh dengan pengisian angket kebutuhan terhadap 2 Guru Biologi dan 5 siswa kelas XII SMA Muhammadiyah 3 Jember, studi pustaka pengembangan buku siswa, analisis KI dan KD bioteknologi kelas XII kurikulum 2013, studi pustaka materi bioteknologi, aplikasi bioteknologi daerah Jember, dan sumber-sumber prespektif Agama Islam terhadap bioteknologi.

Tahap selanjutnya adalah desain yang berupa penentuan judul buku siswa, desain buku (perumusan tujuan pembelajaran dan perancangan sisi media), dan penyusunan instrumen penilaian. Tahap selanjutnya adalah pengembangan yakni tahap perwujudan rancangan menjadi produk yang nyata. Buku siswa yang dikembangan tersebut dinilai kelayakan (validitas), kterbacaan dan kesulitannya. Tahap validasi dilakukan oleh ahli materi, bahasa, pengembangan, media, dan guru Biologi kelas XII SMA Muhammadiyah 3 Jember. Sedangkan uji keterbacaan dan skala terbatas dilaksanakan sebagai uji skala terbatas (kecil).

Tahap implementasi adalah tahap uji coba lapangan dimana buku siswa tersebut diujikan selama proses pembelajaran. Tahap ini digunakan untuk menilai kepraktisan dan efektivitas. Data kepraktisan didapatkan dari pengisisan angket respon siswa dan guru sedangkan data efektivitas diuukur berdasarkan nilai tes bersiklus, pengamatan psikomotorik, dan afektif pada proses pembelajaran yang dilaksanakan dalam satu kelas yakni kelas XII IPA 4 SMA Muhammadiyah 3 Jember. Hasil uji coba lapangan akan memasuki tahap evaluasi akhir untuk memtuskan apakah produk dapat dilanjutkan produksinya atau tidak serta merevisi kembali untuk meningkatkan kualitas buku siswa yang dikembangkan.

\section{Hasil dan Pembahasan}

\section{Analisis (analysis)}

Tahap analisis pada proses awal pengembangan buku siwa berbasis kontekstual bermuatan nilai Agama Islam dilakukan dengan pemberian angket kebutuhan terhadap 2 guru Biologi dan 5 siswa kelas XII SMA Muhammadiyah 3 Jember. Sebesar $100 \%$ guru dan $60 \%$ siswa menyatakan setuju bahwa buku siswa yang digunakan di sekolah kurang berbasis kontekstual. Selain itu, $80 \%$ siswa menyatakan reaksi positif jika mereka kurang memahami batasan-batasan aplikasi bioteknologi berdasarkan norma Agama Islam dan $100 \%$ guru serta siswa menyatakan reaksi negatif jika buku yang digunakan di sekolah telah mengkaitkan materi bioteknologi dengan nilai-nilai Agama Islam. Berdasarkan hal tersebut maka dapat dilanjutkan ke tahap selanjutnya (desain).

\section{Desain (Design)}

Tahap desain yang dilakukan berupa penentuan judul buku siswa yang dikembangkan, perumusan KI dan KD Kurikulum 2013, perumusan tujuan pembelajaran yang harus dicapai setelah menggunakan buku siswa yang dikembangkan, proses pengembangan materi bioteknologi bersifat kontekstual khususnya skala regional (Jember), umunya Nasional (Indonesia) dan Internasional pengembangan keterkaitan materi aplikasi bioteknologi dengan nilai Agama Islam, perancangan sisi media, dan perancangan instrumen penilaian.

Peneliti mulai merancang materi bioteknologi dengan pendekatan kontekstual serta memunculkan inovasi-inovasi produk bioteknologi oleh warga atau ilmuwan di daerah Jember. Hal ini untuk menunjukkan bahwa perkembangan bioteknologi di Jember sangat baik. Selanjutnya peneliti selipkan nilai Agama Islam pada materi-materi yang disajikan yang bersumber dari Al-Qur'an dan Hadist. Nilai Agama Islam yang dikaitkan berguna untuk mengajak siswa semangat mempelajari bioteknologi, mengapresiasi positif bioteknologi, dan membantu siswa untuk mengetahui mana yang benar atau yang salah (batasan-batasan) dari perkembangan aplikasi bioteknologi yang semakin pesat tidak terkendali.

\section{Pengembangan (Development)}

Tahap pengembangan merupakan tahapan ketiga dari model ADDIE yang digunakan dalam penelitian ini. Buku yang telah dirancang kemudian dicetak untuk dinilai oleh para ahli (proses validasi). Validasi merupakan proses untuk menilai apakah rancangan produk efektif atau tidak 
berdasarkan penilaian rasional[14]. Kegiatan validasi merupakan kegiatan mencari dan menentukan hal-hal yang masih harus ditingkatkan atau direvisi agar produk yang dihasilkan lebih efektif dan efisien[8]. Hasil validasi buku siswa oleh validator ahli dapat dilihat pada Tabel 1

Hasil penilaian validasi buku siswa yang dikembangkan (Tabel 1) untuk keseluruhan aspek (materi, bahasam pengembangan, dan media) adalah $83,43 \%$ dengan kategori sangat valid yang artinya buku siswa yang dikembangkan dapat dimanfaatkan di lapangan untuk kegiatan pembelajaran.

Tahap selanjutnya adalah uji skala terbatas untuk menilai keterbacaan dan kesulitan buku siswa yang dikembangkan. Uji terbatas atau uji kelompok kecil bertujuan untuk mengantisipasi kesalahan yang dapat terjadi selama penerapan produk yang sesungguhnya berlangsung. Hal ini juga bermanfaat untuk menganalisis kendala pada saat penerapan produk pada tahap berikutnya[5].

Tabel 2. Hasil Uji Keterbacaan dan Tingkat Kesulitan Buku Siswa

Berdasarkan Tabel 2. rata-rata hasil uji keterbacaan dan tingkat kesulitan buku siswa pada uji skala terbatas sebesar 91,35\% dengan kategori baik. Hal ini menunjukkan bahwa buku siswa siap masuk ke tahap implementasi (uji coba lapangan).

\section{Implementasi (Implementation)}

Tahap implementasi adalah tahap uji coba lapangan dimana buku siswa yang dikembangkan diujikan dalam proses pembelajaran. Tahap implementasi ini diperoleh data kepraktisan dan efektivitas. Aspek kepraktisan merupakan kriteria kualitas perangkat pembelajaran ditinjau dari tingkat kemudahan guru dan siswa dalam menggunakan perangkat pembelajaran yang dikembangkan[9]. Penilaian kepraktisan dalam penelitian ini didapatkan dari angket respon siswa dan guru. Angket respon siswa dan guru diberikan diakhir pembelajaran bioteknologi.

\section{Tabel 3. Nilai Kepraktisan Buku Siswa}

Tabel 3 menunjukkan nilai kepraktisan adalah 80,67\% artinya buku siswa bersifat praktis digunakan dalam proses pembelajaran bioteknologi.

Efektivitas buku siswa yang dikembangkan diukur berdasarkan hasil belajar (kognitif, psikomotorik, dan afektif). Kriteria keberhasilan adalah patokan ukuran tingkat pencapaian prestasi belajar yang mengacu pada kompetensi dasar dan standar kompetensi yang mencirikan penguasaan konsep atau ketrampilan yang dapat diuukur. Kriteria keberhasilan pembelajaran secara umum adalah keberhasilan peserta didik menyelesaikan serangkaian tes dan keberhasilan dihubungkan dengan standar kompetensi dan kompetensi dasar yang ditetapkan oleh kurikulum yang idealnya adalah $75 \%$ [4].

Dalam penelitian ini buku siswa dikatakan efektif apabila minimal 75\% siswa mendapat kategori baik dalam ranah kognitif, psikomotorik, dan afektif. Tabel efektivitas hasil belajar menggunakan buku siswa yang dikembangkan dapat dilihat pada Tabel 4.

Tabel 4. Hasil Belajar
Berdasarkan Tabel 4 menunjukkan bahwa buku siswa yang dikembangkan bersifat efektif terhadap hasil belajar karena minimal 75\% siswa telah mencapai kategori baik.

\section{Evaluasi (Evaluation)}

Peneliti melakukan evaluasi akhir yang dihasilkan dari proses uji coba lapangan. Selama proses pembelajaran menggunakan buku siswa yang dikembangkan, peneliti menemukan hal-hal yang perlu direvisi pada buku agar buku yang dikembangkan semakin baik kualitasnya.

Pengukuran efektivitas buku siswa secara bersiklus dari tahap satu ke tahap berikutnya (dari pertemuan satu ke pertemuan berikutnya) membawa peneliti mengetahui halhal yang perlu diperbaiki atau tidak. Dari hasil tes pada siklus I menunjukkan banyak siswa yang tidak hafal mengenai mikroorganisme yang berperan dalam proses pembuatan beberapa produk bioteknologi karena mereka cenderung meremehkan hal tersebut. Berdasarkan hal ini, peneliti kembali merevisi buku siswa berupa pemberian tugas agar siswa mencari, mempelajari, bahkan menghafal berbagai mikroorganisme yang berperan dalam produk bioteknologi.

Pengamatan proses pembelajaran pada pertemuan kedua peneliti juga menemukan hal-hal yang perlu diperbaiki dalam buku. Selama proses diskusi mengenai materi proses pembentukan tanaman transgenik melalui Agrobacterium tumifacien siswa masih belum memahami secara baik proses tersebut. Berdasarkan hal tersebut maka peneliti kembali melakukan revisi pada buku dimana peneliti menyederhanakan proses modifikasi materi genetik tanaman oleh Agrobacterium tumifacien.

\section{Kesimpulan dan Saran}

Berdasarkan proses pengembangan dan uji coba buku siswa berbasis kontekstual bermuatan nilai-nilai Agama Islam pada materi bioteknologi kelas XII SMA/MA dipaparkan sebagai berikut:

1. Buku siswa yang dikembangkan menyajikan materi bioteknologi bersifat kontekstual pada skala Nasional (Indonesia) dan regional (Jember)

2. Buku siswa yang dikembangkan menyajikan muatan nilai-nilai Islami berupa ayat Al-Qur'an dan Hadist dan fatwa MUI berkaitan aplikasi bioteknologi yang berkembang saat ini

3. Nilai validasi buku siswa yang dikembangkan adalah $83,43 \%$ Nilai kepraktisan buku siswa yang dikembangkan adalah $80,67 \%$ dengan kategori sangat praktis yang artinya buku siswa yang dikembangkan mudah dan senang untuk digunakan. Pembelajaran bioteknologi dengan menggunakan buku siswa yang dikembangkan bersifat efektif yakni minimal 75\% siswa menguasai konsep materi bioteknologi (ranah kognitif), minimal $75 \%$ siswa memiliki kategori baik dalam ketrampilan, dan minimal 75\% siswa memiliki kategori baik dalam sikap.

Berdasarkan hasil penelitian, maka diajukan saran oleh peneliti sebagai berikut:

1. Produk yang dihasilkan perlu ditambahkan dengan buku guru yang berisi pedoman penggunaan buku 
siswa agar bahan ajar tersebut dapat digunakan oleh tenaga pengajar lain dalam kegiatan pembelajaran.

2. Dapat digunakan dalam proses pembelajaran bioteknologi untuk siswa di daerah Jember karena materi bioteknologi dalam buku bersifat kontekstual di Jember sehingga siswa dapat mengembangkan potensi wilayah Jember.

\section{References}

[1] Ampa, A.T., D., M. B., dan A. A. Andriani. 2013. The Development of Contextual Learning Materials for the English Speaking Skills. International Journal of Education and Research. 1(9): 1-10

[2] Atika, S. 2014. Pelaksanaan Pendidikan Karakter (Religius, Cinta Tanah Air dan Disiplin) di SLB Al Ishlah Padang. Jurnal Ilmiah Penidikan Khusus. 3(3): 747-755.

[3] Cahyono, H. 2016. Pendidikan Karakter: Strategi Pendidikan Nilai dalam Membentuk Karakter Religius. Ri'ayah. 1(2): 230-240.

[4] Departemen Pendidikan Nasional. 2008. Kriteria dan Indikator Keberhasilan pembelajaran. Jakarta: Direktorat Tenaga Kependidikan Direktorat Jendral Peningkatan Mutu Pendidik dan Tenaga Kependidikan Departemen Nasional.

[5] Dimyati dan Moedjiono. 2002. Belajar dan Pembelajaran. Jakarta: Rineka Cipta.

[6] Dinata, D. I. 2011. Bioteknologi Pemanfaatan Mikroorganisme dan Teknologi Bioproses. Jakarta: EGC.

[7] Dunham, T., Wells, J. dan K. White, 2002. Biotechnology Education A Multiple Instructional Strategies Approach. Journal of Technology Education. 4(1): 65-81.

[8] Lestari, I. 2013. Pengembangan Bahan Ajar Berbasis Kompetensi. Jakarta: Akademia Permata.

[9] Nieveen, N. 1999. "Prototype to reach product quality. Dlm. van den Akker, J., Branch, R.M., Gustafson, K., Nieveen, N., \& Plomp, T. (pnyt.)". Design approaches and tools in educational and training. Dordrecht: Kluwer Academic Publisher.

[10] Nugroho, E. D. dan D. A. Rahayu. 2017. Pengantar (Teori dan Aplikasi) Bioteknologi. Yogyakarta: Deepublish.

[11] Nursanti, T. E., Umniyatie, S. dan E. Yulianti. 2016. Analisis Kesinambungan Konsep Bioteknologi Dalam Buku Pelajaran Sains/Biologi. Jurnal Pendidikan Biologi. 5(1):1-7.

[12] Purwianingsih, W., Rustaman, N. Y. dan S. Redjeki. 2009. Identifikasi Kesulitan Pembelajaran Bioteknologi pada Guru Seminar Nadional Inovasi Biologi dan Pendidikan Biologi dalam Pengembangan Sumber Daya Manusia.15-16 Juli 2012. Universitas Pendidikan Indonesia: 1-14.

[13] Suardi, M. 2015. Belajar dan Pembelajaran. Yogyakarta: Deepublish.

[14] Sugiyono. 2012. Metode Penelitian Administrasi Dilengkapi dengan Metode R\&D. Bandung: Alfabeta.

[15] Yulianti, T. E. dan A. Rusilowati. 2014. Analisis Buku Ajar Fisika SMA Kelas XI Berdasarkan Muatan Literasi SainS di Kabupaten Tegal. UPEJ. 3(2): 68-72. ISSN 2252-6935. 